\title{
Helping others use social media: age stereotypes when estimating learner's success
}

\author{
Harvey J. GINSBURG, Rebecca CAMERON, Roque V. MENDEZ \& \\ Michael WESTHOFF
}

Texas State University, USA

(Received on February 8, 2015; Accepted on September 22, 2015)

\begin{abstract}
Social networking sites (SNS) include online products such as Facebook that allow users to build and maintain large interpersonal Internet networks. Older adult users have dramatically increased (Duggan \& Smith, 2014). This investigation examined how 212 university undergraduate Facebook users estimated success with helping others use Facebook when learner's age (20, 40, 60 year olds.) and type of acquaintance (friend or kin) was manipulated in hypothetical scenarios. In these scenarios, a person is identified as KW, described as being a college student much like the participant. KW has 20, 40 or 60 year-old acquaintances, a friend or a kin at each age, all wanting KW's help learning about social media. This was the only information provided. Qualities and strengths of these interpersonal relationships were not examined. Results from repeated measures 2x3 ANOVA showed a significant main effect for age, but no effect for acquaintance type. Results showed no significant interaction. Although the age demographic above 50 years is the fastest growing SNS group, results showed possible age stereotyping among youth when they assist older adults learning to use SNS. This age effect may be lessened as older adults become more skillful social media users. These findings are limited because of the sample demographics and a lack of identifying qualities of participants' attributions about the hypothetical friends or relatives. Future research using multiple items per condition might be able to further elucidate how the type of associations between helper and learner, close or distant, positive or negative, would influence outcomes.
\end{abstract}

Keywords: Older adults; ageism; Internet; Facebook.

Ayudando a otros a usar los medios sociales: estereotipos de edad al estimar el éxito del alumno

RESUMEN: Sitios de redes sociales (SNS) como Facebook permiten a usuarios crear y mantener redes de Internet interpersonales. El número de usuarios adultos mayores de edad sigue incrementado (Duggan y Smith, 2014). Esta investigación examinó como 212 estudiantes universitarios usuarios de Facebook calcularon su éxito en ayudar a otros a usar Facebook cuando la edad de la persona a quien ayudaron (20, 40, 60 años) y su conocimiento de la persona a quien ayudaron (amigo o pariente) fue manipulado en escenarios hipotéticos. En estos escenarios, una persona hipotética identificada como KWfue definida como un estudiante universitario al igual que el participante. En cada escenario se supuso que KW tuviera un amigo o pariente de 20, 40 o 60 años de edad quien le pidiera que le enseñara los medios de comunicación social. Esta fue la única información proporcionada. No fueron 
examinadas las cualidades de estas relaciones interpersonales. Los resultados de un 2X3 ANOVA de mediciones repetidas mostraron un efecto significativo para la edad, pero no para conocimiento. Los resultados no mostraron interacción significativa. Aunque los mayores de edad en encima de 50 años es el grupo demográfico que ha visto el más rápido crecimiento de uso de sitios de redes sociales, los resultados mostraron posibles estereotipos entre los jóvenes hacia estos adultos. Este efecto de edad disminuye si los adultos mayores de edad llegan a ser más hábiles en el uso de los medios sociales. Estos resultados son limitados debido a las características demográficas de la muestra y la falta en identificar las cualidades de atribución hechas por los participantes sobre amigos o familiares hipotéticos. Las investigaciones futuras utilizando varias ítems por condición podrían aclarar cómo las asociaciones entre el ayudante y alumno, y la relación cercana o distante de quien ayuda, podrían influir en los resultados.

Palabras clave: Adultos mayores, discriminación por la edad, Internet, Facebook.

Correspondence: Harvey J. Ginsburg, Ph.D. Department of Psychology, 601 University Drive,Texas State University, San Marcos,TX 78666. Contact: hg01@txstate.edu.

\section{Introduction}

Social networking sites (SNS) are defined as online products such as Facebook, Myspace, Twitter, or other websites which focus on maintaining and/or building relationships. Social networking sites have become ubiquitous, adopted on a massive global scale (Gross \& Acquisti, 2005). The daily use of SNS such as Facebook has become routine for a multitude of Internetusers. Boyd and Ellison (2007) noted the first social networking site was developed in 1997. Six degrees.com was the first SNS, sharing several characteristics found in modern social networking sites, allowing its users to create and publicly display their profiles and friends lists to other users. However, by the end of 2006, Facebook had emerged as the most popular SNS, connecting over 12 million active users. Today, Facebook has an estimated 1.2 billion active users; $75 \%$ of Facebook users are from countries other than the United States.

Duggan and Smith (2014) investigated recent SNS use trends for the Pew Research Center. They reported that Facebook is currently the most widely used social media site among adult Internet users. They found the number of people in the U.S. using social networking sites has nearly doubled since 2008, 59\% compared to 34\% of Internetusers. Although youth comprise the largest age demographic, adults over 50 are proportionally the fastest growing age group.

Past research has predominantly focused on user characteristics which predict future use of social media (Baker \& White, 2010). Madden (2010) focused on age patterns for Internet and social media use. Users aged 18-29 years old are among the heaviest users of social networking sites. However, the 50-64 year-old age group far surpasses them in the proportional rates of new users. Internet users in the 50-64 year-old range that admitted to using social networking sites has grown $88 \%$ and $100 \%$ for users 65 and older. Users of social networks do so in order to connect with people from their past. Those nearing the age of retirement may find these connections more valuable as their need for social support increases. Older users are also more likely to have a chronic disease which makes them more likely to seek out support online. Social networking sites may help bridge the generational gap. 
Chung, Park, Wang, Fulk, and McLaughlin (2010) examined different age groups' perceptions of online communities. Those who were studied were not currently participating in these online communities and had not in the past. The researchers used the Technology Acceptance Model to study the factors that influence future intention to partake in these new social communities. The authors found that an individual's perceived usefulness of the site positively influenced behavioral intention. They also found that age, internet self-efficacy and perceived quality of social community websites were all negatively correlated with one another. The authors concluded that perceived usefulness, perceived ease of use, and intention to participate in these online communities did not change with age. However, these authors' conclusion about the reasons for such negative correlations may be misleading. An alternative, and perhaps more plausible conclusion would be that with increasing age, internet self-efficacy and perceived quality of social media decreases. Because they did not grow up using it, older adults may generally have more difficulty mastering nuances of social media. For this reason, the older, new user may have a lessened degree of self-efficacy about their own Internet use abilities. This, in turn, may lead younger users to be less likely to offer assistance. Such age stereotyping would apply to increasing numbers of older SNS users regardless of their experience levels and proficiencies. The possible reduction of older learners' self-efficacy, coupled with perceived higher costs of time and effort may lead to resistance when younger social media users are placed in learning situations with older persons. Regarding age-specific helping with SNS, Brandtaeg, Luders and Skjetne,(2010) found that older adults actually did require more time to learn using SNS, in part validating the age stereotype.

In addition to age effects, a second variable of interest was the type of acquaintance needing help, whether the person is a friend or relative. Hamilton (1964) initially proposed kin selection theory explaining why altruism occurs in many species. His mathematical model showed how the degree of genetic relatedness predicted the probability of helping another. For example, it explained why individual haploid-reproducing insects like ants and honey bees who share more common genes than diploid species, would self-sacrifice for benefit of their closelyrelated colonies. Hamilton's theory predicts that people are more likely to help relatives more than non-relatives and to help a close relative more than a distant one, all things being equal. There may be other obvious influences for helping than kinship. Stewart-Williams (2007) reported that altruism was influenced by the costs of helping and the potential for reciprocal exchange. Despite rival economic and social theories for altruism, genetic kin theory still has proponents and support. Ackerman, Kenrick and Schaller(2007) provided findings supporting their hypothesis that domain-specific affective neurological processes evolved for processing intimate human relationships. The authors proposed that activation occurs as we differentiate feelings about kin and friends. Using an economic model, Vollan (2011) showed that trust and trustworthiness varied substantially for kin, compared to friends. Thus, in addition to possible age differences, acquaintances differences, comparing same-aged friends or relatives was also of interest in this study. Generally, preferring to help relatives more than friends could be a factor predicting how much the helper perceives their success rates teaching SNS skills to new users. Specifically, Hamilton's kin selection theory predicts younger SNS users should be more motivated to have any siblings, parents and grandparents succeed more than same-aged friends.

To date, no research has been conducted examining how young Facebook users feel about helping others learn to use SNS, specifically, their estimated success teaching different- 
aged friends and relatives. The purpose of the present study was to determine how estimated success with helping others learn how to use Facebook varied with learner's age (20, 40, 60 year-olds) and type of acquaintance (friend or kin). The hypotheses were that estimated success for teaching others will significantly decrease with learner's age due to age stereotyping and, that teaching a friend or kin would also produce significantly different success estimates. These hypotheses were examined by using hypothetical scenarios about a university student just like the participant, who might help others learn to use Facebook.

\section{Method}

\section{Participants}

There were 221 participants comprised of 71 males and 148 females, with two participants who did not report their gender. The ages of the participants ranged from 18 to 27 or older, with a mean of 20.37 years; five participants did not report their age. Participants had the following ethnicities:131 were Caucasian, 3 were Native American, 9 were AfricanAmerican, 3 were Asian, 49 were Latino, 16 were multi-racial, 4 identified themselves as other, and 6 preferred not to answer. Inclusion in the data set required they self-reported using Facebook as one of their SNS. Four \% $(\mathrm{N}=9)$ of these participants were removed from the final data set because they self-reported having never used Facebook. Participants were compensated by receiving extra course credit.

\section{Materials and Procedure}

The survey instrument,including hypothetical scenarios for estimating success with helping others use Facebook, was approved by the University IRB prior to data collection. Participants were provided no identifying information; their responses were anonymous.

The first section was comprised of demographic and biographical items. Responses to all subsequent items were based on a 10-point scale, ranging from low (1) to high (10). In the following section, participants were presented with hypothetical scenarios involving a fictional college student named KW whom is depicted as being a college student like the participant. KW uses social networking to keep in touch with friends and family. Participants were instructed to rate KW's perceived success at helping a 20,40, or 60 year-old, who is either KW's friend or family member (hypothetical 20 year-old sibling, 40 year-old parent, or 60 year-old grandparent).A within-subjects factorial design was used. Each participant was presented with the six hypothetical scenarios of20, 40, 60year-old friends, and 20, 40, 60yearoldrelatives. The order of age and type of acquaintance were rotated to preclude potential order effects in the summed data for each age group. This preliminary research was formulated to have respondents estimate the degree of success teaching new learners who were very generally described in the six age and relationships scenarios. KW has a 20, 40 or 60 year-old friend or kin wanting help learning about social media. Only this general information was provided. Qualities and strengths of these interpersonal relationships were not examined. Future research using multiple items per condition might be able to further elucidate how the type of associations between helper and learner, close or distant, positive or negative, would influence outcomes. 


\section{Results}

Estimated success in helping others use Facebook decreased with hypothetical recipients' increases in age. Mauchly's Test of Sphericity was significant $(p<.001)$ with an $\varepsilon(.89)>.75$, indicating that Huynh-Feldt correction should be used to account for unequal variances of the differences between all combined related conditions. A repeated measures Univariate ANOVA showed age differences in estimated learner success, $F(1.802,383.84)=$ 114.42, $p \leq .001$,partial $\eta 2=.349$.Estimated success in helping the 20 year-old learner was highest $(M=7.47, S D=2.17)$, followed by the 40 year-old learner $(M=5.07, S D=2.26)$ and the 60 year-old learner $(M=3.62, S D=2.39)$. A repeated measures t-test showed a significant difference, $t(211)=6.154, p_{\leq} .001$ for the overall estimated success helping either friends $(M=$ $5.07, S D=5.31)$ or relatives $(M=5.59, S D=5.9)$. As age increased, the success estimates significantly decreased for both friends and relatives.

A repeated measures 2x3 ANOVA was performed to determine how age (20, 40, 60 years old) and acquaintance status (friend or relative) influenced participants' responses to their estimated success at facilitating others learning social networking using Facebook. The $M$ and $S D$ for each of the three relative conditions were: 20 year-old learner relative $(M=7.80$, $S D=2.20)$, 40 year-old learner relative $(M=5.36, S D=2.44), 60$ year-old learner relative ( $M$ $=3.74, S D=2.59$ ). The $\mathrm{M}$ and $S D$ for each of the three friend conditions were: 20 year-old learner friend $(M=7.15, S D=2.49), 40$ year-old learner friend $(M=4.77, \mathrm{SD}=2.43), 60$ year-old learner friend $(M=3.49, S D=2.56)$ with total age $\mathrm{x}$ friend $(M=5.39, S D=2.59)$. For all ages and the total scores, relatives always showed higher $M$ than friends.

Mauchly's Test of Sphericity was significant, $p<.001, \varepsilon(.916)>.75$, indicating that Huynh-Feldt correction should be used to account for unequal variances of the differences between all combined related conditions. Results from repeated measures 3 (age) x 2 (acquaintance) ANOVA showed significant main effects for age, $F(1.847,3.89 .617)=171.305$, $p \leq .001$. No significant main effect was shown for acquaintance type, $F(1,211)=1.71, p=$ .193 ;forage, partial $\eta 2=.059$ and for acquaintances, partial $\eta 2=.008$. No significant age $x$ acquaintance interaction was observed.

Learner's age produced the predicted significant effect on estimated success. Surprisingly, whether the learner was friend or kin, acquaintance status showed no main effect. There was no significant age $\mathrm{x}$ acquaintance interaction. All Bonferrenipost-hoc paired comparisons showed significant differences when success estimates based upon learner attributes were compared.

\section{Discussion}

These present findings suggest that SNS learner's age is a more salient factor than acquaintance status in estimated success for facilitating social networking use. Hamilton's formulation of genetic relation as the basis of altruism was not supported by these findings. Recently, Nowak, Tarnita and Wilson (2010) have refuted Hamilton's kin selection theory by showing how the initial mathematical formulation was inaccurate and that most haploid insects show no altruism as predicted by the theory. Honey bees and ants showing altruism were 
selectively identified by proponents of kin selection theory while the great majority of noneusocial haploid insects were ignored.

Madden(2010) previously noted that $86 \%$ of 18-29 year-olds use social media sites, compared to $50 \%$ of $50-64$ year-olds and $26 \%$ of 65 years and older using social networking. Brandtaeg, Lüders, and Skjetne(2010) found that younger users were more skilled in their Facebook usage, whereas adults over the age of 40 had difficulties in understanding the navigation logic and privacy settings. Therefore, the amount of perceived help needed for the participants' own age group would be affected by their own age cohorts' ample experiences with social networking and technology in general. Thus, among young adults, their cohorts may be perceived as having different and stronger motivation to learn more about SNS. As a larger proportion of older adults use SNS, these perceptions may change. However, both younger and older adults often displayed completely open public profiles without realizing it, with multiple privacy issues being a persistent Facebook issue (Carruth and Ginsburg, 2014).Thus, even younger, experienced SNS users can be susceptible to misjudging important factors like privacy; such mistakes are not isolated to older, less experienced users.

Currently, Internet users 50 years and older are the fastest growing age group using social media, and proportionally more rapid use is among those 65 years and older (Madden, 2010; Duggan and Smith, 2014). Today, the older age cohort, on average, is still less experienced in social networking use but is in the process of assimilating the social networking experience. Perhaps age stereotyping about learner's age would play a role in the participants' estimated success teaching an older person how to use Facebook, regardless of that older person's actual technology proficiency. The SNS landscape is ever-changing and growing with emergent newer and more popular sites. Although the proportion of senior users has increased dramatically, they must also assimilate this constant flux of SNS change to improve negative perceptions about their facility with them.

This age effect may be lessened as older adults become more skillful social media users. These findings are limited because of the sample demographics and a lack of identifying qualities of participants' attributions about the hypothetical friends or relatives. Future research using multiple items per condition might be able to further elucidate how the type of associations between helper and learner, close or distant, positive or negative, would influence outcomes.

There are several potential gains from having more elderly people access SNS. Cruwys, Dinagle et al. (2013) reported that among 60-95 year-old vulnerable adults, learning how to use Internet social media increased their general sense of self-efficacy, social interactions, and improved cognitive abilities. The authors suggested that elderly SNS use may decrease depressive symptoms and prevent future depression .Cottena, Ford, Ford and Halea (2013) have reported that Internet use among senior citizens reduced depressive symptoms by 30 $\%$,compared to non-users.

There are also implications concerning measures for safeguarding older SNS users that people advising senior citizens should consider. Older, new users may be particularly vulnerable to Internet investment and health misinformation. Directing them to several online communities offering social support information and courses about Internet and SNS uses for senior citizens may also be useful, including AARP, SeniorNet.com, SeniorPlanet.com, and SeniorSite.com (Chait 2013). 
Smartphones use among those aged 55 years or older has also dramatically increased (Carracher 2011). Smartphones can enable senior citizens to easily access SNS and explore websites of interest, manage daily routines, and even monitor early signs of neglect or abuse. As smartphone use becomes ubiquitous among the next generation of older adults, the types of attitude stereotyping reported here may show a considerable decline.

\section{References}

Ackerman J.M., Kenrick D.T., \& Schaller M. (2007). Is friendship akin to kinship? Evolution and Human Behavior, 5, 365-374.

Baker, R., \& White, K. (2010). Predicting adolescents' use of social networking sites from an extended theory of planned behaviour perspective. Computers in Human Behavior, 26, 1591-1597.

Bentler, P., \& Speckart, G. (1979). Models of attitude-behavior relations. Psychological Review, 86(5), 452-464.

Boyd, D. M., \& Ellison,N. B. (2007). Social network sites: Definition, history, and scholarship. Journal of Computer-Mediated Communication, 13(1), 210-230.

Brandtzæg, P., Luders, M., \& Skjetne, J. (2010). Too Many Facebook' Friends'? Content Sharing and Sociability Versus the Need for Privacy in Social Network Sites. International Journal of Human-Computer Interaction, 26(11/12),1006-1030.

Carracher, J. (2011). How Baby Boomers Are Embracing Digital Media. Mashable. Retrieved from http://mashable.com/2011/04/06/baby-boomers-digital-media/.

Carruth, K.A. \& Ginsburg, H. (2014). Social networking and privacy attitudes among College students. Psychology, Education \& Society,6 (2), 37-47.

Chait, J. (2013). Finding a Senior Citizen Online Community. Senior Citizen Online Community. Retrieved fromhttp://seniors.lovetoknow.com/Senior_Citizen_Online_Community.

Chung, J., Park, N., Wang, H., Fulk, J., \& McLaughlin, M. (2010). Age differences in perceptions of online community participation among non-users: An extension of the Technology Acceptance Model. Computers in Human Behavior, 26(6), 1674-1684.

Cottena,S. R., Ford G., Ford S., \& Halea, T.M. (2012). Internet use and depression among older adults. Computers in Human Behavior, 28 (2), 496-499.

Cruwys, T., Dingle, G.A., Haslam, S.A., Haslam, C., Jetten, J., \&Morton T.A. (2013). Social group memberships protect against future depression, alleviate depression symptoms and prevent depression relapse. Social Science and Medicine, 98, 179-186.

Duggan M. \& Smith, A. (2014). Social Media Update 2013. Pew Research Center. Retrieved from http://pewInternet.org/Reports/2013/Social-Media-Update.aspx

Gross, R. \&Acquisti,A. (2005). Information Revelation and Privacy in Online Social Networks, WPES'05- VirginiaUSA, pp. 71- 78.

Hamilton, W. D. (1964). The Genetical Evolution of Social Behaviour. Journal of Theoretical Biology, 7 (1), 1-16.

Madden, M. (2010). Older adults and social media. Retrieved from http://pewinternet.org/Reports/2010/Older-Adults-and-Social-Media.aspx

Nowak, M.A., Tarnita, C.E. \& Wilson, E.O. (2010). The evolution of eusociality. Nature, 466, 1057-1062. 
Stewart-Williams, S. (2007). Altruism among kin vs. non-kin: Effects of cost of help and reciprocal exchange. Evolution and Human Behavior, 28(3), 193-198.

Vollan, B. (2011)'The difference between kinship and friendship: (Field-) experimental evidence on trust and punishment. The Journal of Socio-Economics, 40 (1), 14-25. 